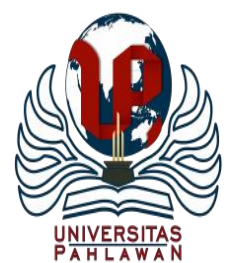

Edukatif : Jurnal Ilmu Pendidikan Volume 3 Nomor 5 Tahun 2021 Halm 2749 - 2759

EDUKATIF: JURNAL ILMU PENDIDIKAN

Research \& Learning in Education

https://edukatif.org/index.php/edukatif/index

\title{
Peningkatan Prestasi Belajar Tema Peristiwa Alam melalui Metode Demonstrasi dengan Berbantuan Media Pembelajaran Microsoft Sway di Sekolah Dasar
}

\author{
Pungky Saheriestyan $^{1 凶}$, Nurita Primasatya ${ }^{2}$, Elissyarifatul Hidayah $^{3}$ \\ Universitas Nusantara PGRI Kediri, Indonesia ${ }^{1,2}$ \\ Sekolah Dasar Negeri Burengan 2, Indonesia ${ }^{3}$ \\ E-mail : $\underline{\text { saheriesyan@ gmail.com }}^{1}, \underline{\text { nurita.primasatya@ gmail.com }}^{2}$, \\ elissyarifatulhidayah93@guru.sd.belajar.id ${ }^{3}$
}

\begin{abstract}
Abstrak
Penelitian ini dilatarbelakangi oleh belum tuntasnya pemahaman siswa dalam muatan matematika, sehingga memerlukan perbaikan dari segi sistem pembelajaran. Adapun yang menjadi tujuan dari penelitian ini ialah untuk mengetahui metode demonstrasi dengan berbantuan media pembelajaran microsoft sway dapat meningkatkan prestasi belajar siswa kelas 1 pada tema Peristiwa Alam. Metode penelitian ini adalah Penelitian Tindakan Kelas yang dilakukan dengan melalui 2 siklus dengan tahapan perencanaan, pelaksanaan tindakan, pengamatan, serta refleksi. Hasil dari penelitian ini menunjukkan bahwa terjadi peningkatan prestasi belajar siswa, dari pra-siklus, siklus I ke siklus II. Pada pra-skilus, rata-rata nilai prestasi belajar siswa hanya sebesar 65,71 dengan presentase ketuntasan 32,14\%. Setelah diberikan tindakan berupa pembelajaran melalui metode demonstrasi dengan berbantuan media pembelajaran microsoft sway ketuntasan prestasi belajar siswa pada siklus I mencapai hingga 73,21 dengan presentase ketuntasan sebesar 50\%. Pada siklus II mengalami peningkatan prestasi belajar siswa hingga diperoleh rata-rata nilai mencapai 80,36 dengan presentase ketuntasan sebesar 75\%. Dengan demikian, dari hasil penelitian dapat ditarik kesimpulan bahwa melalui metode demonstrasi dengan berbantuan media pembelajaran microsoft sway dapat meningkatkan prestasi belajar siswa kelas 1 pada tema Peristiwa Alam.
\end{abstract}

Kata Kunci: Prestasi belajar, peristiwa alam, metode demonstrasi, microsoft sway.

\begin{abstract}
This research is motivated by the unfinished understanding of students in the content of mathematics, so it requires improvements in terms of the learning system. The purpose of this research is to find out the demonstration method with Microsoft Sway-assisted learning media can improve the learning achievement of grade 1 students on the Natural Events theme. This research is Classroom Action Research which is carried out through 2 cycles with the stages of planning, actions, observing, and reflecting. The results of this study indicate that there is an increase in student achievement, from pre-cycle, cycle I to cycle II. In the pre-cycle, the average value of student achievement is only 65.71 with a mastery percentage of $32.14 \%$. After being given action in the form of learning through the demonstration method with learning media microsoft sway, student achievement completeness in cycle I reached 73.21 with a percentage of completeness of $50 \%$. In the second cycle there was an increase in student achievement until the average score reached 80.36 with a percentage of completeness of $75 \%$. It can be concluded that through demonstrations using Microsoft Sway learning media, it can improve student achievement in grade 1 on the Natural Events theme.
\end{abstract}

Keywords: Learning achievement, natural events, demonstration method, microsoft sway.

Copyright (c) 2021 Pungky Saheriestyan, Nurita Primasatya, Elissyarifatul Hidayah

$\triangle$ Corresponding author

Email : saheriesyan@gmail.com

DOI $\quad$ : https://doi.org/10.31004/edukatif.v3i5.919

ISSN 2656-8063 (Media Cetak)

ISSN 2656-8071 (Media Online) 
2750 Peningkatan Prestasi Belajar Tema Peristiwa Alam melalui Metode Demonstrasi dengan Berbantuan Media Pembelajaran Microsoft Sway di Sekolah Dasar - Pungky Saheriestyan, Nurita Primasatya, Elissyarifatul Hidayah

DOI: https://doi.org/10.31004/edukatif.v3i5.919

\section{PENDAHULUAN}

Pada awal Maret 2020 seluruh warga Indonesia di resahkan dengan adanya penyebaran virus covid-19 di Indonesia. Virus tersebut di awal kemunculannya tidak begitu mengkhawatirkan bagi masyarakat Indonesia, namun seiring berjalannya waktu virus tersebut menimbulkan peningkatan yang signifikan terhadap angka kematian di Indonesia. Kondisi ini memberikan dampak yang sangat besar terhadap sektor pendidikan. Mulai dari tingkat Sekolah Dasar hingga Perguruan Tinggi. Ditengah kondisi pandemi covid-19 seperti saat ini, pemerintahpun mengambil kebijakan tegas dalam menghindari berbagai kemungkinan penyebaran virus covid-19. Salah satunya dengan menerapkan kebijakan PJJ (Pembelajaran Jarak Jauh). Kebijakan tersebut menerapkan sistem pembelajaran yang dilakukan secara daring atau online. Dalam pelaksanaan sistem pembelajaran tersebut, memberikan tantangan yang berbeda bagi para pengajar, institusi, pembelajar, serta masyarakat luas (Latip, 2020). Kebijakan tersebut dilakukan oleh pemerintah agar dapat meminimalisir berbagai kemungkinan penyebaran virus yang terjadi di sektor pendidikan.

Dari pengertiannya, pendidikan ialah usaha sadar serta bersifat terencana sehingga dapat mewujudkan dan mencipkatan suasana belajar serta proses pembelajaran, dengan demikian peserta didik mampu secara aktif melakukan pengembangan atas potensi pada dirinya agar dapat memiliki kekuatan spiritual kegamaan, kepribadian, pengendalian diri, akhlak mulia, serta keterampilan yang diperlukan dirinya, masyarakat, bangsa dan negara (UU RI No. 20, 2003). Banyak pihak yang berpendapat serta mengakui bahwa pendidikan merupakan bentuk investasi yang bersifat jangka panjang, dengan demikian setiap manusia akan memiliki hak dalam hal memperoleh pendidikan tanpa pengecualian. Adapun peranan dari pendidikan sangatlah besar dalam hal mempersiapkan serta mengembangkan SDM (Sumber Daya Manusia) yang tergolong handal, mampu dalam bersaing dengan kondisi sehat, memiliki jiwa kebersamaan dan saling membutuhkan antar manusia (Alpian, 2019). Kemudian, mengingat pentingnya pendidikan dalam mengembangkan taraf dari kehidupan manusia. Maka, seseorang diharapkan untuk dapat belajar dengan melalui pendidikan terencana. Hal tersebut sesuai dengan program pemerintahan agar dapat mewajibkan pada setiap warga negaranya untuk memperoleh pendidikan dalam kurun waktu selama 12 tahun. Adapun mulai dari jenjang pendidikan Sekolah Dasar hingga Sekolah Menengah Atas (Peraturan Menteri Pendidikan \& Kebudayaan Nomor 19, 2016). Sebelum menempuh ke pendidikan yang lebih tinggi. Maka setiap orang harus menempuh pendidikan Sekolah Dasar terlebih dahulu. Dalam hal ini pendidikan sekolah dasar dapat memberikan serta menjadi bekal kepada siswa agar bisa mengembangkan potensi diri siswa, sehingga dapat melanjutkan ke pendidikan berikutnya dengan jenjang yang lebih tinggi. Beberapa mata pelajaran di sekolah dasar pada kurikulum 2013 dijadikan satu cakupan pada satu pembelajaran. Pembelajaran tersebut sekarang dikenal dengan mata pelajaran tematik. Adapun salah satu mata pelajaran yang terintegrasi pada muatan pelajaran tematik adalah pendidikan matematika.

Pendidikan matematika di sekolah dasar merupakan salah satu muatan pelajaran yang berkontribusi positif untuk tercapainya masyarakat yang cerdas dan mampu bersaing dikehidupan selanjutnya. Pendidikan matematika adalah mata pelajaran yang mempelajari tentang kemampuan dalam berhitung, pengurangan, perkalian, pembagian, mengukur, serta memahami bentuk geometri. Novitasari (2016) menyatakan bahwa, suatu pelajaran yang memiliki hubungan ataupun keterkaitan dengan berbagai konsep. Dalam hal ini ialah konsep dalam matematika memiliki hubungan dengan satu hal dan lainnya. Oleh sebab itu, pembelajaran matematika perlu diberikan sejak mulai dari jenjang pendidikan sekolah dasar untuk membekali siswa agar mampu berpikir logis, analitis, sistematis, kritis dan kreatif, serta mampu bekerja sama. Hal ini sejalan dengan yang disampaikan oleh Primasatya \& Imron (2020) yang mengatakan bahwa kemampuan 4C (Critical Thinking, creative thinking, communication, and collaboration) merupakan kemampuan yang perlu ditanamkan sejak dini. Namun, tidak bisa dipungkiri bahwasannya sekarang pembelajaran tidak hanya 
2751 Peningkatan Prestasi Belajar Tema Peristiwa Alam melalui Metode Demonstrasi dengan Berbantuan Media Pembelajaran Microsoft Sway di Sekolah Dasar - Pungky Saheriestyan, Nurita Primasatya, Elissyarifatul Hidayah

DOI: https://doi.org/10.31004/edukatif.v3i5.919

mengacu pada buku dan penjelasan guru. Terlebih saat pembelajaran sekarang yang dilakukan melalui online/daring. Guru dituntut harus bisa mempunyai inovasi dalam menyampaikan materi pembelajaran dengan memanfaatkan penggunaan media dan metode untuk mendukung jalannya pembelajaran.

Seluruh siswa kelas 1A di SD Negeri Burengan 2 Kota Kediri telah mengenal pendidikan di TK/RA sebelumnya. Dengan bekal kesadaran dan pentingnya pendidikan yang cukup memadai, tetapi masih terdapat siswa yang mengalami kesulitan dalam pembelajaran, khususnya muatan matematika. Terlebih pada saat ini siswa kelas 1 selama ini hanya melakukan pembelajaran jarak jauh sehingga mengakibatkan kemaun belajar menurun dan berdampak pada nilai pretasi belajar siswa. Hal ini dibuktikan dengan hasil prestasi belajar siswa pada tema 7 menunjukkan 25\% dari 28 siswa belum tuntas dalam menelaah materi pembelajaran. Dari pernyataan guru kelas 1A SDN Burengan 2, menyatakan lebih dari 50\% siswa kebanyakan belum memahami soal yang bermuatan matematika, sehingga kesalahan mengerjakan soal kebanyakan pada muatan matematika. Hal ini juga terlihat pada saat tes pra-siklus yang telah dilakukan oleh peneliti, yang menunjukkan hasil nilai rata-rata kelas hanya mencapai 65,71 , dengan presentase ketuntasan $32,14 \%$.

Dari hal tersebut, peneliti berinisiatif melakukan sebuah tindakan untuk memecahkan permasalahan bagaimana siswa dapat tertarik dalam pembelajaran jarak jauh, sehingga materi yang disampaikan bisa dimaknai dan berdampak pada peningkatan hasil prestasi belajar siswa, khususnya pada muatan matematika tema Peristiwa Alam. Dengan sebuah desain solusi melalui metode demonstrasi dengan berbantuan media pembelajaran microsoft sway yang dilakukan oleh peneliti diharapkan dapat menarik simpati dan minat belajar siswa. Peneliti melakukan penelitian ini dikarenakan selama pembelajaran jarak jauh, guru lebih sering menggunakan metode penugasan melalui media whatsapp group saja yang terkesan sangat monoton, sehingga siswa merasa kurang tertarik untuk belajar dan tidak bisa memaknai pembelajaran dengan baik. Yang membedakan penelitian ini dengan penelitian lainnya adalah, bahwa penelitian ini merupakan inovasi yang menggabungkan antara metode demonstrasi dengan berbantuan microsoft sway, yang mana sejauh ini belum ada penelitian terdahulu yang menggabungkan dua variabel tersebut.

Segala (2011:210) menyatakan, metode demonstrasi ialah metode yang berguna untuk mempertunjukkan proses atau cara kerja pada suatu benda yang berhubungan dengan materi pelajaran. Majid (2014:155) menyatakan, bahwa karakteristik pada metode demonstrasi sebenarnya untuk menyampaikan pembelajaran pada siswa dalam penangkapan proses melaui objek tertentu. Pelaksanaan metode demonstrasi selain yang dilakukan oleh guru sebagai model, juga dapat dilakukan oleh narasumber untuk mendemonstrasikan objek materi pelajaran. Majid (2015) juga menyatakan, bahwa metode demonstrasi memiliki kelebihan menuntut siswa aktif saat proses pembelajaran, maksutnya siswa memperhatikan materi pelajaran yang dijelaskan oleh demonstran secara langsung, sehingga siswa mampu untuk membandingkan antara teori dan kenyataannya dan pada akhirnya dapat meyakini kebenaran materi dari pembelajaran. Melalui metode demonstrasi diharapkan siswa dapat mengembangkan kemampuan dalam pengamatan benda maupun situasi saat proses pembelajaran, serta siswa dapat mengambil kesimpulan-kesimpulan makna dari pembelajaran. Kemudian proses penerimaan materi pembelajaran dapat terkesan secara mendalam bagi siswa, sehingga membentuk pengertian yang baik dan bermakna.

Disamping itu untuk menyampaikan materi pembelajaran tersebut dibutuhkan media yang dapat mudah diakses oleh siswa. Salah satunya adalah media interaktif yang juga mendukung proses pembelajaran pada masa pandemi seperti ini. Microsoft sway merupakan alternatif media untuk menunjang pembelajaran jarak jauh. Menurut Kulsum, (2020) dalam penelitiannya menyatakan melaui desain tampilan objek microsoft sway yang sangat menarik dapat meningkatkan gairah belajar peserta didik. Fitur yang terdapat pada microsoft sway dapat merangsang otak peserta didik. Sebagai pendukung pendapat tersebut, Ardian (2020) menyatakan bahwa kelebihan pada microsoft sway diantaranya adalah dapat digunakan sebagai media audio, video, gambar tanpa harus mengunduhnya, desain sesuai dengan materi yang sesuai dengan bidangnya, dapat 

Pembelajaran Microsoft Sway di Sekolah Dasar - Pungky Saheriestyan, Nurita Primasatya, Elissyarifatul Hidayah

DOI: https://doi.org/10.31004/edukatif.v3i5.919

menambah fitur presensi kelas dan soal pada microsoft form, dapat melihat siapa saja yang berpartisipasi, dan apabila koneksi tidak stabil, maka presensi kelas atau soal yang sudah ditambahkan otomatis akan menjadi link. Dengan bantuan media pembelajaran microsoft sway dapat membantu peneliti dalam meneruskan materi yang akan didemonstrasikan kepada siswa.

Berdasarkan hal tersebut maka peneliti tertarik untuk melakukan kajian lebih dalam lagi dengan melakukan Penelitian Tindakan Kelas (PTK) mengambil judul "Peningkatan Prestasi Belajar Tema Peristiwa Alam melalui Metode Demonstrasi dengan berbantuan Media Pembelajaran Microsoft sway pada Siswa Kelas 1" yang bertujuan untuk mengetahui metode demonstrasi dengan berbantuan media pembelajaran microsoft sway dapat meningkatkan prestasi belajar siswa kelas 1A SD Negeri Burengan 2 Kota Kediri pada muatan matematika tema Peristiwa Alam.

\section{METODE PENELITIAN}

Jenis penelitian ini adalah Penelitian Tindakan Kelas (PTK). Menurut Arikunto (2015) menyatakan bahwa penelitian tindakan kelas merupakan penelitian yang memaparkan proses maupun hasil dengan tujuan untuk meningkatkan kualitas pembelajarannya. Desain prosedur untuk meningkatkan kualitas pembelajaran pada penelitian ini dilakukan melalui 2 siklus dengan tahapan perencanaan, pelaksanaan tindakan, pengamatan, serta refleksi. Subyek dan setting pada penelitian ini adalah siswa kelas 1A SDN Burengan 2 Kota Kediri tahun ajaran 2020/2021 yang berjumlah 28 siswa, terdiri dari laki-laki berjumlah 17 siswa dan perempuan berjumlah 11 siswa. Peneliti memilih kelas 1A SDN Burengan 2 Kota Kediri sebagai subjek penelitian, karena ditemukan terdapat permasalahan yang telah dijelaskan pada latar belakang.

Metode analisis data yang digunakan pada penelitian ini adalah melalui data kuantitatif. Nurjannah, dkk. (2021), menyatakan bahwa data kuantitatif diperoleh melalui tes hasil belajar siswa untuk mengukur sejauh mana peningkatan hasil prestasi belajar siswa yang diperoleh. Untuk mencari nilai rata-rata kelas dan presentase ketuntasan hasil belajar siswa menggunakan operasi penjumlahan setiap skor/ total skor dibagi dengan banyaknya siswa yang memiliki skor dan dikalikan 100. Sehingga rumus yang digunakan untuk menghitung rata-rata kelas dan presentase ketuntasan hasil prestasi belajar siswa adalah:

1. Menghitung nilai rata-rata kelas

$\mathrm{X}=\frac{\sum N s}{\sum s} \times 100$

Keterangan:

$\mathrm{X}=$ Nilai rata-rata kelas

$\sum N s \quad=$ Jumlah nilai tes siswa

$\sum s \quad=$ Jumlah siswa yang mengikuti tes

2. Menghitung presentase ketuntasan hasil belajar siswa

$\mathrm{X}=\frac{R}{N} \times 100 \%$

Keterangan:

$\mathrm{X}=$ Presentase ketuntasan hasil belajar siswa

$\mathrm{R}$ = Jumlah siswa yang tuntas belajar

$\mathrm{N}$ = Banyaknya siswa 
2753 Peningkatan Prestasi Belajar Tema Peristiwa Alam melalui Metode Demonstrasi dengan Berbantuan Media Pembelajaran Microsoft Sway di Sekolah Dasar - Pungky Saheriestyan, Nurita Primasatya, Elissyarifatul

Hidayah

DOI: https://doi.org/10.31004/edukatif.v3i5.919

\section{HASIL DAN PEMBAHASAN PENELITIAN}

\section{Pra Siklus}

Pra Siklus penelitian tindakan kelas atau tes sebelum perbaikan pembelajaran ini dilakukan pada hari Rabu, tanggal 28 April 2021 saat pertemuan tatap muka di kelas. Hasil pre-test digunakan untuk mengukur sejauh mana pengetahuan siswa mengenai muatan matematika tema peristiwa alam. Hasil pre-test juga digunakan untuk pedoman pada kegiatan perbaikan pembelajaran di setiap siklusnya.

Hasil tes sebelum perbaikan pembelajaran dapat dilihat pada tabel berikut:

Tabel 1 Perolehan Nilai Pre-test dan Presentase

\begin{tabular}{ccc}
\hline Nilai & Banyak Siswa & Presentase \\
\hline 30 & 2 & $7,14 \%$ \\
\hline 40 & 2 & $7,14 \%$ \\
\hline 50 & 4 & $14,29 \%$ \\
\hline 60 & 3 & $10,72 \%$ \\
\hline 70 & 8 & $28,57 \%$ \\
\hline 80 & 6 & $21,43 \%$ \\
\hline 90 & 2 & $7,14 \%$ \\
\hline 100 & 1 & $3,57 \%$ \\
\hline Jumlah & 28 & $100 \%$ \\
\hline \multicolumn{3}{c}{ Rata-rata } \\
\hline \multicolumn{3}{|c|}{ Ketuntasan } \\
\hline
\end{tabular}

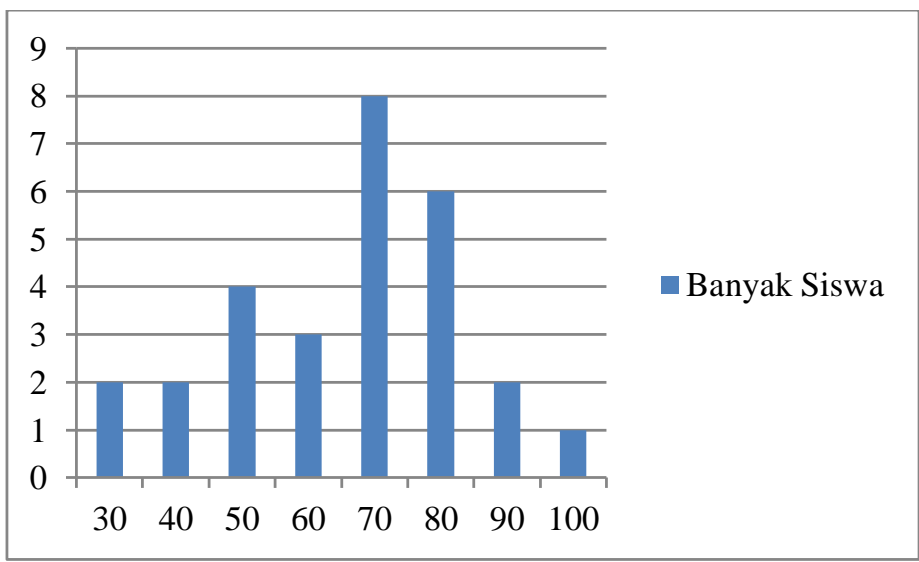

Gambar 1 : Nilai Pre-test

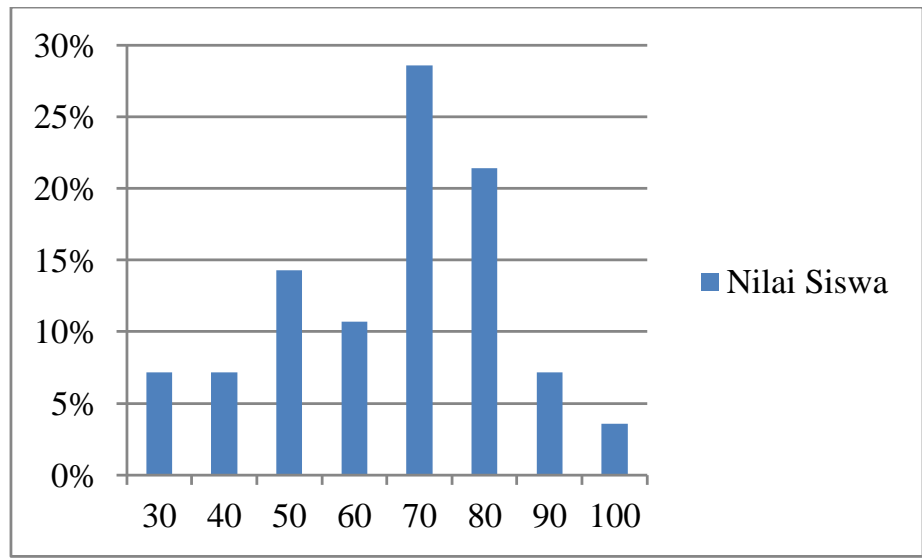

Gambar 2 : Presentase ketuntasan hasil Pre-test

Edukatif : Jurnal Ilmu Pendidikan Vol 3 No 5 Tahun 2021 p-ISSN 2656-8063 e-ISSN 2656-8071 
Diketahui bahwa nilai KKM pada siswa kelas 1 SDN Burengan 2 Kota Kediri adalah 75. Dari tabel dan grafik pengamatan hasil pre-test diatas diperoleh jumlah siswa yang dinyatakan tuntas sebanyak 9 siswa atau jika dipresentasekan hanya 32,14\%, sehingga sisanya 19 siswa atau jika dipresentasekan mencapai $67,86 \%$ dinyatakan belum tuntas. Sedangkan rata-rata kelas yang diperoleh dari hasil prestasi belajar saat pra-siklus adalah 65,71 .

\section{Siklus I}

Dari data hasil pra siklus atau tes sebelum perbaikan pembelajaran menunjukkan masih sangat rendah prestasi belajar siswa pada muatan matematika peristiwa alam. Oleh karenanya, hasil perbaikan pembelajaran dilakukan pada siklus I pada hari Senin, tanggal 24 Mei 2021 dengan menggunakan metode demonstrasi dengan berbantuan media pembelajaran microsoft sway.

Pada siklus I ini, kegiatan pembelajaran dilakukan oleh peneliti sesuai dengan perencanaan awal yakni pembelajaran secara online menggunakan metode demonstrasi dari video dengan berbantuan media pembelajaran microsoft sway. Saat penelitian, pencarian data nilai prestasi belajar siswa pada siklus I ini menggunakan tes formatif. Berikut adalah hasil nilai prestasi belajar siswa dari tes formatif yang diberikan:

Tabel 2. Perolehan Nilai Siklus I dan Persentase

\begin{tabular}{ccc}
\hline Nilai & Banyak Siswa & Presentase \\
\hline 30 & 0 & $0 \%$ \\
\hline 40 & 2 & $7,14 \%$ \\
\hline 50 & 2 & $7,14 \%$ \\
\hline 60 & 4 & $14,29 \%$ \\
\hline 70 & 6 & $21,43 \%$ \\
\hline 80 & 7 & $25 \%$ \\
\hline 90 & 5 & $17,86 \%$ \\
\hline 100 & 2 & $7,14 \%$ \\
\hline Jumlah & 28 & $100 \%$ \\
\hline & Rata-rata & $\mathbf{7 3 , 2 1}$ \\
\hline & Ketuntasan & $\mathbf{5 0 \%}$ \\
\hline
\end{tabular}

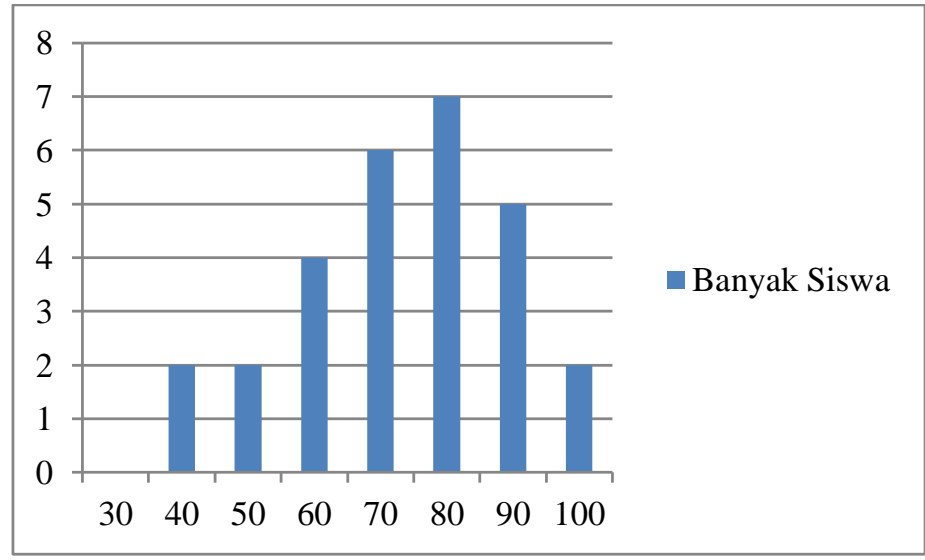

Gambar 3 : Nilai Evaluasi Siswa Siklus I 

Pembelajaran Microsoft Sway di Sekolah Dasar - Pungky Saheriestyan, Nurita Primasatya, Elissyarifatul Hidayah

DOI: https://doi.org/10.31004/edukatif.v3i5.919

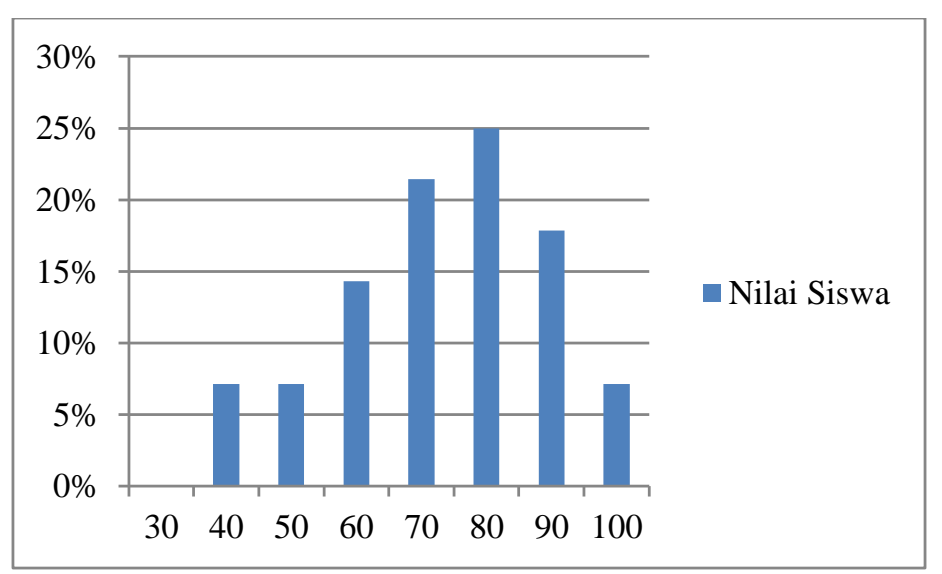

Gambar 4 : Presentase Ketuntasan Hasil Evaluasi Siklus I

Tabel dan grafik penelitian menunjukkan bahwa hasil prestasi belajar siswa pada siklus I setelah mendapat tindakan jauh lebih baik dari sebelumnya. sebanyak 14 siswa atau jika dipresentasekan 50\% telah dinyatakan tuntas dalam menelaah muatan matematika pada tema peristiwa alam. Sedangkan 14 siswa atau 50\% lainnya masih belum dinyatakan tuntas. Sehingga rata-rata nilai kelas secara klasikal diperoleh 73,21. Rata-rata tersebut hampir mendekati nilai 75, tetapi masih dibawah KKM dan belum bisa dinyatakan berhasil.

\section{Siklus II}

Hasil dari siklus I menunjukkan bahwa ada peningkatan hasil prestasi belajar siswa dari nilai pra-siklus. Namun terdapat beberapa hambatan-hambatan yang terjadi, seperti: a) karena metode demonstrasi dengan berbantuan media pembelajaran microsoft sway ini belum pernah dilakukan, maka masih menjadi kebingungan dari siswa dan wali siswa dalam pengoperasiannya, sehingga materi yang dipelajari menjadi kurang maksimal; b) soal evaluasi yang diberikan untuk mengukur hasil prestasi belajar siswa, bahasanya sulit dipahami bagi siswa, sehingga mengalami kesulitan dalam mengartikan maksud dari pertanyaan tersebut.

Seperti penelitian yang dilakukan oleh Chrismawati, dkk. (2021) penelitian melakukan refleksi dari hal yang perlu diperbaiki untuk dilanjutkan pada siklus II. Berbekal dari pengalaman hambatan pada siklus I, perlu dilakukan perbaikan pembelajaran berikutnya pada siklus II dengan harapan dapat memperbaiki permasalahan pada siklus I yang akan mempengaruhi hasil prestasi belajar siswa dengan tindakan; a) menjelaskan kepada wali dari siswa dan siswa sendiri mengenai cara pengoperasian media pembelajaran microsoft sway dengan mengirimkan video tutorialnya. Peneliti juga menyampaikan ulang materi pembelajaran saat pertemuan tatap muka di kelas menggunakan metode demonstrasi; b) peneliti bersama kolabolator mempersiapkan soal evaluasi dengan bahasa yang mudah dipahami oleh siswa, namun tidak mengurangi bobot soal dari siklus sebelumnya/siklus I. Siklus II dilakukan pada hari Kamis, tanggal 27 Mei 2021 dengan menggunakan metode demonstrasi dengan berbantuan media pembelajaran microsoft sway yang telah diatur menjadi lebih baik lagi dari sebelumnya.

Pada siklus II ini direncanakan dengan memperhatikan kekurangan-kekurangan pada siklus I. Hal ini dilakukan dengan harapan dapat lebih meningkatkan sistem pembelajaran dari pada siklus sebelumnya. Berikut adalah hasil nilai prestasi belajar siswa dari tes formatif yang diberikan:

Tabel 3. Perolehan Nilai Siklus II dan Persentase

\begin{tabular}{ccc}
\hline Nilai & Banyak Siswa & Presentase \\
\hline 30 & 0 & $0 \%$ \\
\hline 40 & 0 & $0 \%$ \\
\hline 50 & 2 & $7,14 \%$ \\
\hline
\end{tabular}


2756 Peningkatan Prestasi Belajar Tema Peristiwa Alam melalui Metode Demonstrasi dengan Berbantuan Media Pembelajaran Microsoft Sway di Sekolah Dasar - Pungky Saheriestyan, Nurita Primasatya, Elissyarifatul Hidayah

DOI: https://doi.org/10.31004/edukatif.v3i5.919

\begin{tabular}{ccc}
\hline 60 & 3 & $10,72 \%$ \\
\hline 70 & 2 & $7,14 \%$ \\
\hline 80 & 9 & $32,14 \%$ \\
\hline 90 & 9 & $32,14 \%$ \\
\hline 100 & 3 & $10,72 \%$ \\
\hline Jumlah & 28 & $100 \%$ \\
\hline \multicolumn{3}{c}{ Rata-rata } \\
Ketuntasan & $\mathbf{8 0 , 3 6}$ \\
\hline
\end{tabular}

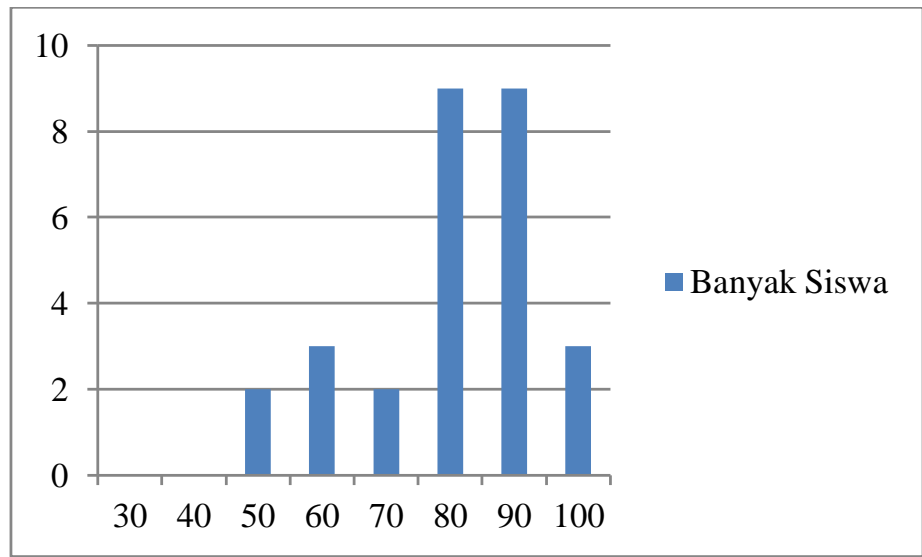

Gambar 5. Nilai Evaluasi Siswa Siklus II

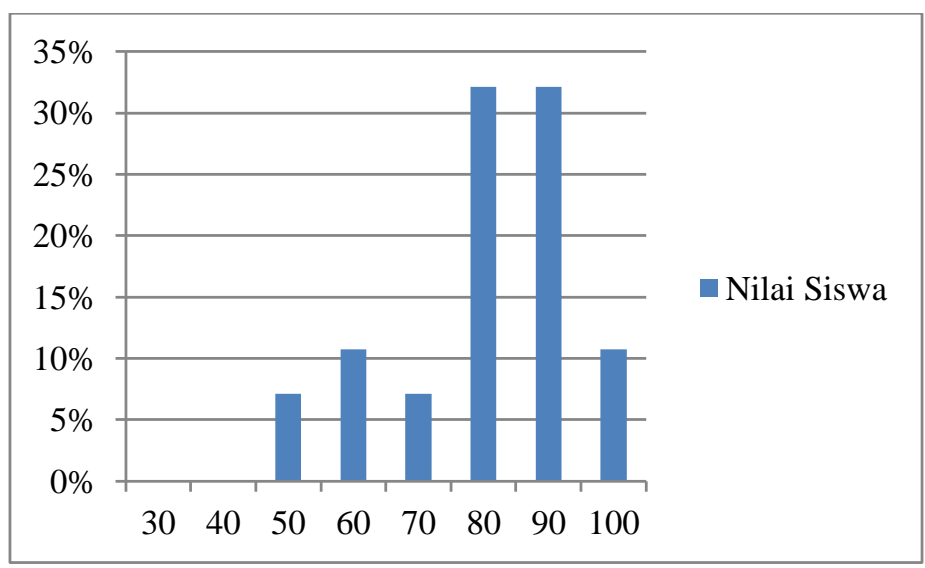

Gambar 6. Presentase Ketuntasan Hasil Evaluasi Siklus II

Data tabel dan grafik diatas menunjukkan bahwa siswa yang memperoleh nilai diatas KKM pada siklus II ini meningkat, yakni sebanyak 21 siswa atau $75 \%$. Sedangkan siswa yang belum bisa mencapai nilai KKM sebanyak 7 siswa atau jika dipresentasekan sebesar 25\%. Sehingga diperoleh rata-rata nilai kelas secara klasikal adalah 80,36. Ini menunjukkan bahwa hasil prestasi belajar siswa mengalami peningkatan dari siklus sebelumnya.

Penelitian yang dilakukan di SDN Burengan 2 Kota Kediri ini, mendapatkan data bahwa mengalami perubahan dan peningkatan pada hasil prestasi belajar siswa disetiap siklusnya. Bukti peningkatan prestasi belajar siswa melalui metode demonstrasi dengan berbantuan media pembelajaran microsoft sway pada muatan matematika tema Peristiwa Alam terlihat pada rekapitulasi tabel berikut: 
2757 Peningkatan Prestasi Belajar Tema Peristiwa Alam melalui Metode Demonstrasi dengan Berbantuan Media Pembelajaran Microsoft Sway di Sekolah Dasar - Pungky Saheriestyan, Nurita Primasatya, Elissyarifatul Hidayah

DOI: https://doi.org/10.31004/edukatif.v3i5.919

Tabel 4. Perbandingan rata-rata dan presentase ketuntasan nilai pra-siklus sampai siklus II

\begin{tabular}{ccc}
\hline Siklus & $\begin{array}{c}\text { Rata-rata Nilai } \\
\text { Kelas }\end{array}$ & $\begin{array}{c}\text { Persentase } \\
\text { ketuntasan }\end{array}$ \\
\hline Pra-siklus & 65,71 & $32,14 \%$ \\
\hline Siklus I & 73,21 & $50 \%$ \\
\hline Siklus II & 80,36 & $75 \%$ \\
\hline
\end{tabular}

Sebuah desain solusi yang telah dilakukan oleh peneliti ini menunjukkan bahwa metode demonstrasi dengan berbantuan media microsoft sway dapat mempengaruhi prestasi belajar siswa. Penggunaan metode demonstrasi yang diberikan melalui video dan beberapa fitur lainnya yang dimiliki oleh media pembelajaran jarak jauh yang dinamakan microsoft sway ini sangat membantu menarik simpati belajar siswa dan membuat pembelajaran tersebut tidak membosankan. Terlebih media pembelajaran Microsoft sway dapat dikatakan sebagai media pembelajaran asinkronus yang artinya dapat diakses berulang-ulang, kapan saja dan dimana saja. Sehingga berpengaruh pula pada hasil prestasi belajar pada siswa. Terbukti pada hasil penelitian di atas bahwa metode demonstrasi dan media microsoft sway adalah faktor yang mempengaruhinya.

Faktor yang mempengaruhi hasil prestasi belajar siswa, salah satunya yaitu metode demonstrasi. Pada penelitian ini metode demonstrasi diberikan melalui video yang yang mendemonstrasikan materi muatan matematika pada tema Peristiwa Alam melalui link media pembelajaran microsoft sway yang diberikan di whatsapp group. Metode demonstrasi sebagai metode pembelajaran yang kegiatannya berupa memperagakan materi secara langsung sehingga akan meningkatkan proses pembelajaran matematika dan berdampak pada peningkatan hasil prestasi belajar siswa (Nugraha \& Suyatmin, 2021). Hal ini juga sejalan dengan penelitian yang dilakukan oleh Syahputri (2018), yang menyatakan media pembelajaran matematika sekolah dasar kelas 1 dengan menggunakan metode demonstrasi sangat berguna untuk meningkatkan minat belajar siswa terkhusus pada muatan matematika, sehingga akan berdampak pada prestasi belajar pula. Pembelajaran tematik melalui metode demonstrasi dengan berbantuan media pembelajaran microsoft sway dapat memberikan pengalaman bermakna kepada siswa kelas 1A SDN Burengan 2 Kota Kediri, mengingat ini adalah pertama kalinya media pembelajaran microsoft sway dilakukan di masa pandemi seperti ini.

Adanya bantuan dari media pembelajaran microsoft sway pada penerapan metode demonstrasi sangat membantu dalam penyampaian materi kepada siswa, sehingga siswa dapat tertarik dan memaknai materi pembelajaran yang telah diberikan dan berdampak pada peningkatan prestasi belajar siswa. Sejalan dengan penelitian Raharjo, dkk. (2020), dari hasil penelitiannya menunjukkan adanya peningkatan terhadap motivasi belajar siswa pada pembelajaran tematik melalui penerapan media sway yang dilakukan pada pembelajaran daring. Dari penelitian yag dilakukan oleh Munawaroh (2021), melalui penerapan aplikasi sway dapat meningkatkan hasil belajar siswa dengan dibuktikan peningkatan pada setiap siklusnya. Penelitian yang dilakukan oleh Widiastuti, dkk. (2019), menegaskan pembelajaran dengan menggunakan microsoft sway dapat meningkatkan gairah belajar siswa karena media ini adalah salah satu media pembelajaran yang kondusif dan bermakna, selain itu proses saat terjadinya pembelajaran menjadi lebih bervariasi dan menarik minat belajar siswa.

Pada penelitian ini terdapat keterbatasan yang mempengaruhi peneliti, sehingga penelitian belum dapat dikatakan maksimal. Adapun keterbatasan tersebut, seperti: 1) penelitian ini adalah pertama kali dilakukan, yang artinya belum ada penelitian yang hampir sama dengan variabel penelitian ini, sehingga peneliti cukup kesulitan untuk membandingkan dengan penelitian lain; 2) penelitian ini hanya melakukan tindakan sebanyak 2 siklus saja, dikarenakan kendala oleh waktu yang mendekati penilaian akhir semester dan jika penelitian ini dapat dilanjutkan ke siklus berikutnya kemungkinan akan mendapatkan hasil yang lebih baik lagi; 3) 
2758 Peningkatan Prestasi Belajar Tema Peristiwa Alam melalui Metode Demonstrasi dengan Berbantuan Media Pembelajaran Microsoft Sway di Sekolah Dasar - Pungky Saheriestyan, Nurita Primasatya, Elissyarifatul Hidayah

DOI: https://doi.org/10.31004/edukatif.v3i5.919

keterbatasan waktu yang diberikan ketika proses pembelajaran, sehingga saat proses evaluasi untuk mendapatkan hasil prestasi belajar kurang maksimal.

Hasil dari penelitian ini dimaknai sebagai desain solusi pembelajaran jarak jauh, sehingga pembelajaran tidak monoton yang membuat siswa menjadi bosan dan berdampak pada prestasi belajar siswa menurun. Penelitian ini khususnya ditujukan kepada pihak sekolah, baik kepala sekolah sebagai koordinator maupun guru kelas sebagai alternatif dalam pembelajaran daring. Seperti halnya dengan itu, bahwasannya metode demonstrasi dengan berbantuan media pembelajaran microsoft sway terbukti dapat meningkatkan prestasi belajar siswa pada tema Peristiwa Alam siswa kelas 1A SD Negeri Burengan 2 Kota Kediri tahun pelajaran 2020/2021 yang dilakukan oleh peneliti.

\section{KESIMPULAN}

Berdasarkan hasil dan pembahasan tersebut maka dapat disimpulkan bahwa penelitian tindakan kelas ini dapat meningkatkan hasil prestasi belajar siswa melalui metode demonstrasi dengan berbantuan media pembelajaran microsoft sway pada muatan matematika tema Peristiwa Alam yang dilakukan di SD Negeri Burengan 2 Kota Kediri pada siswa kelas 1A tahun pelajaran 2020/2021 yang berjumlah 28 siswa. Hasil penelitian ini menunjukkan bahwa setiap siklus mengalami peningkatan, dari mulai pra-siklus, siklus I, hingga siklus II. Peningkatan hasil prestasi belajar siswa dapat dilihat dari meningkatnya rata-rata dan presentase dari mulai awal atau pra-siklus, siklus I, sampai dengan siklus II. Pada pra-siklus didapat nilai rata-rata semula hanya mencapai 65,71 , pada siklus I mengalami peningkatan menjadi 73,21 , dan peningkatan juga terjadi pada siklus II nilai rata-rata kelas menjadi 80,36 . Selain nilai rata-rata kelas, persentase ketuntasan juga menjadi bukti bahwa hasil prestasi belajar siswa mengalami peningkatan. Pada pra-siklus persentase ketuntasan hanya mencapai 32,14\% atau 9 siswa saja, pada siklus I mengalami peningkatan menjadi 50\% atau 14 siswa, pada siklus II juga mengalami peningkatan sebesar 25\% dari siklus I sehingga ketuntasan menjadi $75 \%$ atau 21 siswa.

\section{UCAPAN TERIMA KASIH}

Atas tersusunnya artikel ini tidak luput dari bantuan sejumlah pihak, sehingga penulis ingin mengucapkan terima kasih kepada dosen pembimbing, kepala sekolah, guru, dan siswa SDN Burengan 2 Kediri, serta pihak lainnya yang memberikan dukungan baik materil maupun non materil kepada penulis sehingga penulisan artikel ini berjalan dengan lancar.

\section{DAFTAR PUSTAKA}

Alpian, Yayan, D. (2019). Pentingnya Pendidikan Bagi Manusia. Jurnal Buana Pengabdian, 1(1), 66-72.

Ardian, Satrio, Hasanah, W. Kisty, \& Rana, F. I. (2020). Pemanfaatan Microsoft Sway Dan Microsoft Form Sebagai Media Interaktif Dalam Pembelajaran Sejarah. Jurnal Bihari: Pendidikan Sejarah Dan Ilmu Sejarah, 3(1), 66-74.

Arikunto, Suharsimi, Supardi, Dan S. (2015). Penelitian Tindakan Kelas. Jakarta: Bumi Aksara.

Chrismawati Mirna , Ika Septiana, E. D. P. (2021). Edukatif : Jurnal Ilmu Pendidikan Peningkatan Hasil Belajar Ipa Dengan Discovery Learning Berbantuan Media Audio Visual Di Sekolah Dasar. Edukatif: Jurnal Ilmu Pendidikan, 3(3), 1928-1934.

Kulsum, Umi. (2020). Motivasi Belajar Peserta Didik Pada Masa Pandemi Covid-19 Dengan Microsoft Sway. Proceeding International Webinar On Malay Local Wisdom In The Period And After The Plague, 
2759 Peningkatan Prestasi Belajar Tema Peristiwa Alam melalui Metode Demonstrasi dengan Berbantuan Media Pembelajaran Microsoft Sway di Sekolah Dasar - Pungky Saheriestyan, Nurita Primasatya, Elissyarifatul Hidayah

DOI: https://doi.org/10.31004/edukatif.v3i5.919

Yogyakarta: 13 Juni 2020. Hal. 65-72.

Latip, A. (2020). Peran Literasi Teknologi Informasi Dan Komunikasi Pada Pembelajaran Jarak Jauh Di Masa Pandemi Covid-19. Eduteach: Jurnal Edukasi Dan Teknologi Pembelajaran, 1(2), 108-116.

Majid, A. (2014). Pembelajaran Tematik Terpadu. Bandung: Remaja Rosdakarya.

Majid, A. (2015). Perencanaan Pembelajaran. Bandung: Pt Remaja Rosdakarya.

Munawaroh, S. (2021). Meningkatkan Hasil Belajar Siswa Melalui Penerapan Aplikasi Sway Pada Mata Pelajaran Produksi Olahan Diversifikasi Hasil Perikanan. Jurnal Kreatif Onlien (Jko), 9(1), 113-120.

Novitasari, D. (2016). Pengaruh Penggunaan Multimedia Interaktif Terhadap Kemampuan Pemahaman Konsep Matematis Siswa. Jurnal Pendidikan Matematika \& Matematika, 2(2), 8-18.

Nugraha, Asep Eka, \& S. (2021). Peningkatan Hasil Belajar Dan Aktivitas Belajar Siswa Melalui Penggunaan Metode Demonstrasi Pada Mata Pelajaran Matematika Di Sd Negeri 2 Neglasari Tasikmalaya. Jiees: Journal Of Islamic Education At Elementary School, 2(1), 12-21.

Nurjannah, Arisah, N, \& Ampa, A, T. (2021). Penerapan Model Pembelajaran Berbasis Masalah (Problem Based Learning) Dalam Meningkatkan Hasil Belajar Siswa Pada Mata Pelajaran Kewirausahaan Di Kelas X Ap.1 Smk Negeri 1 Marioriawa Kabupaten Soppeng. Jurnal Pendidikan Ekonomi Dan Kewirausahaan, 4(1), 24-33.

Peraturan Menteri Pendidikan \& Kebudayaan Nomor 19. (2016). Peraturan Menteri Pendidikan Dan Kebudayaan Republik Indonesia Nomor 19 Tahun 2016 Tentang Program Indonesia Pintar.

Primasatya, Nurita \& Imron, I. F. (2020). Analysis Of Student Needs Of The Mathematics Club (Mc) As A Co-Curricular Activities As An Effort To Grow Up 4c Skills. Jurnal Math Educator Nusantara, 6(2), 215-223.

Raharjo, Fanis Sofyan, Sulistiyono, Roni Dan Widyastuti, N. S. (2020). Penerapan Model Problem Based Learning Dan Media Sway Secara Daring Terhadap Motivasi Belajar Siswa Pada Pembelajaran Tematik Di Kelas Iii Sd Unggulan 'Aisyiyah Bantul.

Segala, S. (2011). Konsep Dan Makna Pembelajaran. Jakarta: Alfabet.

Syahputri, N. (2018). Rancang Bangun Media Pembelajaran Matematika Sekolah Dasar Kelas 1 Menggunakan Metode Demonstrasi. Jurnal Sistem Informasi Kaputama, 2(1), 89-95.

Uu Ri No. 20. (2003). Tentang Sistem Pendidikan Nasional. Bandung: Citra Umbara.

Widiastuti, L., \& Wiyarno, Y. (2019). Pengembangan Media Pembelajaran Berbasis Sway Pada Mata Pelajaran Teknologi Informasi Dan Komunikasi. Teknodik Journal, 23(4), 163-174. 